\title{
Does Road Investment Really Promote the Export? Evidence from Sichuan County-level Data of China
}

\author{
Lihe $\mathrm{Xu}^{1}$, Jiaqi Liu ${ }^{2}$, Xiaoshan Yan $^{1}$ \\ ${ }^{1}$ Research Fellow, Guangdong Institute for International Strategies (GIIS), Guangdong University of Foreign Studies \\ (GDUFS) \\ ${ }^{2}$ Master, Xiamen University, China \\ Correspondence: Lihe Xu, Room 409, Guangdong Institute for International Strategies (GIIS), North of Baiyun Street \\ \#2, Guangzhou, Guangdong 510420, China.
}

Received: March 27, 2018 Accepted: April 23, 2018 Online Published: May 24, 2018

doi:10.5539/res.v10n2p197 URL: https://doi.org/10.5539/res.v10n2p197

\begin{abstract}
Whether road infrastructure promotes export is still a concerned issue debated in the previous studies. In this paper, we conduct a panel data using two data sources from year 2003 to 2013, examining the relationship between road investment and export. The primary results show that road investment significantly restricts local export. A further test indicates that the road infrastructure benefits service sector, 1) abstract more private capital investment on service sector than manufacturing sector, 2) reduce the employee of tradable sector. Then manufacturing sector was constrained. The results are robust when a set test is carried out.
\end{abstract}

Keywords: Road investment, Export, New registered firm, China

JEL: O14, F16, R4

\section{Introduction}

Road infrastructure is often mentioned as a key to promote the export. The argument relies on the simple logic that "market access" or "local road density" may reduce transportation cost, or rise the manufactory productivity directly (Shirley and Winston, 2004; Donaldson, 2010; Li and Li, 2013). However, most of these studies assume that for fixed endowment in better connected or integrated areas, tradable goods move to the market more easily than the capital and labor (eg., Banerjee et al., 2012), ignore its direct or indirect effect on the non-tradable sectors (i.e., construction, transportation, hotel, etc.), which may "crowd-out" the tradable sectors ${ }^{1}$. And limited literature consider that non-tradable sector may react faster than the tradable goods (eg., Song et al.,2014), and non-skill labor may likely mobile between tradable and non-tradable sectors.

This paper contributes the literature by focusing on the mechanism of road infrastructure investments impact on export, which includes both tradable and non-tradable sectoral channels at county-level of Sichuan province in China from 2003 to $2013^{\text {iiii }}$. In other words, besides the road investment effect on the tradable sector directly, we further consider its effect on non-tradable sectors, which may back to impact on the tradable sector indirectly. Sichuan province is under-development area, includes 138 counties local at the southwestern of China. In 2000, China central government began an active program of investment in the development regions called "Western Development Strategy" (also known as "Go West") (see eg., Yao, 2009; Fan et al., 2011). But mostly after 2008, the investment is implement vigorously. Fan et al. (2013) point out: "For Sichuan province, on the other hand, much of policy making is now seen through the prism of the consequences of and responses to the massive earthquake of 2008". Most of investment flow into the road, the average length of each county rises from around $930 \mathrm{~km}$ to $1245 \mathrm{~km}$ before and after 2007(see, figure 1. (A)). The roughing growth rate is only $1.5 \%$ every year before 2007 , and after 2007 it reaches to $7.2 \%$ every year. Consistence with this patterns, after China entry in to the WTO, only from 2003, the Sichuan county has reported their export information, and it also boom from 2007, rough growth rate is from 50.4\% every year to $62.6 \%$ before and after 2007 , which is more higher than the road investment (see figure 1. (B)). Besides that, the counties within a province share the same language, cultural, policy institute and nature resources, more homogenous than cross province or countries data. These characteristics provide us a "quality data set" to estimation the relationship between road investment and export. 


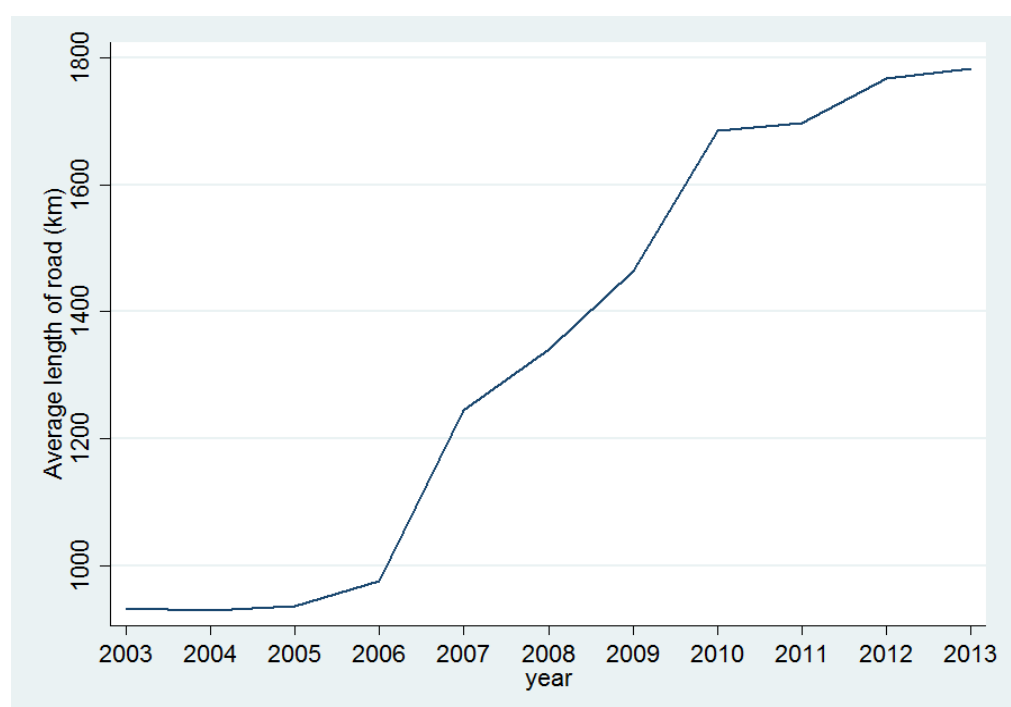

(A) Average road length of Sichuan County in China

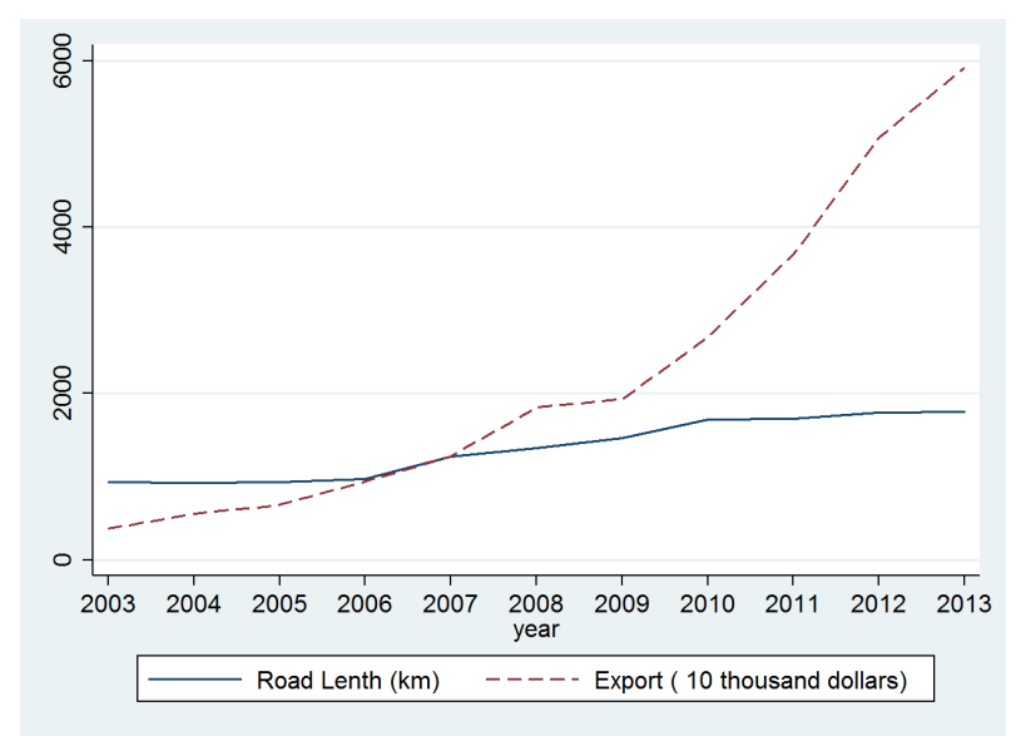

(B) Average Road length and Export of Sichuan County in China

Figure 1. Road length and export in Sichuan province, China

To identify the road investment effect on export with directly and indirectly mechanism, we conduct a penal data combine the new register firm data from Administration of Industry and Commerce of Sichuan and fundamental economics' variables. Rather than focus on market access hypothesis, which only consider market integration impact on the tradable sectors through the price convergence in difference areas by trade models ${ }^{\text {iii. }}$. Follow the previous literature, this paper choose three measurements as proxy of the road infrastructure investment, i.e. road length road to area density, road to population density, to estimate its effect on export through both tradable and non-tradable sectors. And assume that the relative price will change in short run after road investment flow into the local market, that is the price of non-tradable goods may be raised immediately caused by increasing demand of service sector, such as, construction, transport, hotel etc., compared with the tradable goods determined by the international market, then labor and capital will flow to the non-tradable sectors, so the manufacturing may be restricted in short term.

This strategy has a number of advantages. First, it provides us with an estimation of indirect effect export on through non-tradable sectors. Second, this combination mechanism effect can be distinguished by testing the labor and capital flow by sectors. We can therefore ask the short run level effect of better road investment. Third, period 2003 - 2013, coincides with China become a WTO member and export growth. Therefore, these counties are in the good position to exploit the road investment effect on the export. 
The primary finds that road investment hinder the local county's export. It means that better road area has less export. To further investigate, we find that road investment have different effect on the two sectors of economics. Because road investment increases higher demand of local non-tradable goods, but the demand of tradable goods is determined by the international market. Hence, the relative price between service and manufacturing sector in short run is rising. During the process of price coverage to the equilibrium level, road investment will first cause a large labor demand in local market (i.e., construction), the average wage is increasing. On the one hand, employee share of manufacturing are reduced by the road investment, more non-skill labor will move from the manufacturing to service sector, such as a worker becomes as builder, waiter or track driver etc. the manufacturing firms face the shortage of labor because their relative lower wage. On the other hand, the private capital will also flow to the service sector more than manufacturing sector. Because given the wage equal to labor marginal production, service sectors' productivity is increasing caused by the higher demand of non-trade goods. This result consistence with Song et al. (2014)'s finding, which road investment increase the demand for service sector, such as housing, restaurant and so on. Both of these two effects, road investment restrict the local export significantly.

For the discussion, it is important to keep three points in mind. First, we focus on the short term effect. When the road investment in the local area, in short run, it may rise the demand of non- tradable goods, and relative price and labor demand of non-tradable goods is increased, the average wage of local area is increasing at the end. But price of tradable goods is determined by international market, non-skill labor move from labor-intensive manufacturing firm to non-tradable sectors (Bulte et al., 2018). In other word, the price volatility is deference by sectors, and wage gap are exist between two sectors. Second, for all counties in our analysis sample, we assume the county faces the same "market access" opportunity within a same province, but different local road density. Third, our results do not implicate the road investment is worse for the economics, but focus on showing its different effects by sectors.

The remainder of the paper is organized as follows. Section 2 discusses the related literature, and section 3 shows the details of identification, section 4 introductions the data. In section 5, report and analysis the empirical result. Section 6 concludes and discusses limitation.

\section{Literature Review}

There are two literature to test and explain the relationship between road infrastructure investment and export. One is called "Market Access" hypothesis, this studies argue that the road or railroad connected the local area with the global market, the tradable goods can be easily and low-cost to sale to the global market, local area benefit from this market integration (Fogel 1964, Donaldson 2010; Banerjee et al., 2012; Donaldson and Hornbeck, 2012). A lot of empirical papers test above hypothesis and find that that road infrastructure has positive effect using many countries' evidences. Farhadi (2015) find that the stock of infrastructure will promote the productivity in OECD countries in the long run. Donaldson (2010) find the railroad investment increase the export caused by reducing the transport cost and it interregional price gap in India. Michaels (2008) find the similar effect using highway road data of United State. But these effects may not be stable in China. Banerjee et al. (2012) argue that the highway road has moderate effect on the GDP per capita of China, and insignificant effect by sectors. Faber (2014) finds that China's trunk highway has a negative impact on industrial development. However, Most of these studies focus on the estimation strategy to avoid the endogeneity, but little discuss the mechanism which may has more contribute the economic. All of market access hypothesis only focus on aggregate effect of the tradable sectors, and assume the price will converge in the long run between different areas with the better infrastructure connected. In other words, above studies' conclude that infrastructure investment benefit the total social welfare. However, the better connected rural regions to cities may cause the skilled labor migrant from rural to urban ${ }^{\text {iv }}$, and rural receive very limited benefits from these effect (Jacoby, 2000).

"Local road density" hypothesis try to test the channel of road effect on economics. There are some evidences, such as, Shirley and Winston (2004) using USA data, and Li and Li (2013) using province -level data of China, Holl (2016) using the data of Spanish have found that the road investment will reduce the firm's inventory and increase the manufacturing productivity of local area. But these concludes are debating, some studies argue that the road density may not only effect on the tradable sector, but also effect on other non-tradable sector, and these two effect may linkage (Banerjee et al., 2012). The labor will flow to the higher wage sectors, and the capital will also flow to the higher productivity sectors, given the wage equal to the marginal productivity, both labor and capital will move to higher productivity sector. Song et al. (2014) point out that the infrastructure investment has positive impact on primary industry firstly, then is the tertiary industry, the last is the second industry. Addition that, non-tradable sector's reaction may "crowd-in" or "crowed- out" the manufacturing development in short run. In other words, labor or capital may move within two sectors, because the relative price may be shaped (Bulte et al., 2018). Better road density counties have the higher productivity of service sectors and more service enterprises (Gao et al., 2015). Hence, deduce these findings, we point out counter-intuitive hypothesis. 
Hypothesis 1. Road infrastructure may restrict the local export.

Hypothesis 2. Road infrastructure has higher positive effect on the service sector than manufacturing sector.

\section{Identification}

To capture the above effect, we use a very simple model to test the hypothesis.

First, we use fixe effect model to eliminate the invisible county heterogeneity:

$$
\log \left(\exp \operatorname{ort}_{i t}\right)={\beta \operatorname{Road}_{i t-1}}+X_{i t}^{\prime} \delta+t+u_{i}+\varepsilon_{i, t}
$$

export represents the total export in county $i$ at year $t$. Road represents the total length. And in order to avoid the heterogeneity effect at difference counties, such as, the far county local at the mountain area may has less population, and distribution of population is not centralize, so they has higher length but little manufacturing firms. We use density of area and population to avoid this bias. Road density may not be used well at the same period, such as, new investment on road today, the local firm may not benefit today but may be tomorrow, so we use the lag stock of road to measure these effect. Moreover, less industrialize counties has less export, but may has better road density because it focus on the development the agricultural or service industry, such as tourism. In order to avoid this kind of sample selection bias, we control as set of variables X', that is GDP per capita, population, area, government revenue, local labors' education (measured by average number of middle school students). Besides, that, the popularity of telephone will help enterprises reduce the cost of the information in the economic activities, so we take the local mobile phone users to represent it, and we also use urbanization rate as a proxy of industrialization rate. $t$ is the year fixed effect, $u$ represents the county fixed effect, $\varepsilon$ is the random error. $\beta$ represents the sensitive of the total export to the transportation infrastructure investment.

As for the endogeneity problem, a major concern with our estimating model is reverse causality problem. Such as, road investment may centralize at the higher export area, which a main channel to increase the economic growth. In order to resolve these possible endogeneity problems, we have adopted a variety of methods. First of all, the lag variable of traffic infrastructure can control the volume of causal relationship between transportation infrastructure and export. The strategy does not distinguish the target of road investment policy, this only test whether after road investment, local export will be promoted or not. Second, we use panel data fixed effects model to control the unobserved omitted variables bias. Third, we control the industrialization rate of county to measure the development of export sector.

The equation (1) test the hypothesis that the whether the road effect on export. Following this logic, we also provide the examination of hypothesis 2, which test its mechanism of road effect. As discussed in section 2, if we only consider the short term effect with the relative price has been changed, labor and capital may flow into the non-tradable sectors. Hence, we use the new registered firm numbers by sector as a proxy of private capital, and use employment share by sectors measure the labor movement, instead of export to re-regress the model (1). If the road investment has positive effect on the private capital and labor on service industry, or negative effect on manufacturing sector, then one potential effect channel has been proofed (more detail see in Section 5).

\section{The Data}

This paper uses data from multiple sources. First, all of fundmental economics, i.e., export, GDP per capita, employment share by sectors, population, area, education, urbanization rate, etc., are obtained from Sichuan Statistical Yearbooks of China from 2003-2013 published in 2004 to 2014. All of counties report their export data only began at 2003 after China become a WTO member. Second, New Registered Firm numbers by sectors are collected and calculated according main business merge with National Economical Industry Classification (GB/T4754-2011) by authors, where it comes from Administration of Industry and Commerce of Sichuan Province in China . This data is different from the other data set. It include all size, industrial, property of firms, such as large scale and small firms, manufacturing or service industry, state-owned, private, or foreign etc., which provide us an opportunity to capture almost all capital resource flow into which sectors after road investment. And we first calculate the firm numbers according industrial classification, and then aggregate into county-level according the registered address.

There are 138 counties local at Sichuan Province, and we exclude the district of city (37 districts distribute in 21 cities) because two main reasons: 1) district is difference from counties because they are centralized in the city, if we treat them as homogenous, the industrial cluster or agglomerate effect cannot be distinguished; 2) road length are reported exclude the street data, but include the village connection road. However, not all of counties report these variables we used every year, such as, the export and road data is omitted in Daocheng county in year 2008 and 2010. At the end, total sample size of fundamental economics are 1307 within 138 counties of 11 years, but imbalance.

Table 1 reports the summary statistics of all variables. On the average, each county exports 27,300 thousand dollars every year. There are 213 firms registered in each year, and 24 are manufacture firms, 138 are service firms. And 57.8 
thousands labor work at industrial sector, but 82.3 thousands labor work at service sectors. Total road length of each county is $1,392 \mathrm{~km}, 48.6 \mathrm{~km}$ per square area, the average area of county is 2,780 square kilometers. And $806.7 \mathrm{~km}$ per thousand population, which each county has 529 thousand persons. And income of county is 13,807 yuan per capita, government revenue has 271.6 million yuan in average, 28.0 thousand kids educated at middle school level. And 158.8 thousand phones are used within a county. $18.3 \%$ live in the urban area.

Table 1. Summary Statistics

\begin{tabular}{llllll}
\hline Variable & $\mathrm{N}$ & Mean & Std. Dev. & Min & Max \\
\hline \multicolumn{1}{c}{ Independent variables } & & & & & \\
Export ( thousand Dollars) & 1307 & 27,300 & 141,702 & 0 & $2,918,100$ \\
Total new firm No. & 1307 & 213 & 206 & 0 & 1,652 \\
Manufacture firm No. & 1307 & 24 & 34 & 0 & 365 \\
Service firm No. & 1307 & 138 & 154 & 0 & 1,406 \\
employment of industrial ( thousand) & 1307 & 57.80 & 56.01 & 0.10 & 372.10 \\
employ of service ( thousand) & 1307 & 82.25 & 69.65 & 0.80 & 344.00 \\
$\quad 1307$ & & & & \\
$\quad$ Dependent variables & 1307 & 1392.09 & 1024.34 & 119.00 & 12034.00 \\
Road (km) & 1307 & 48.61 & 61.91 & 3.49 & 538.46 \\
Road/area (km/million sq km) & 1307 & 806.64 & 789.16 & 31.59 & 17093.80 \\
Road/Population (km/thousand) & 1307 & 13807.42 & 10250.44 & 2095.00 & 61965.00 \\
GDP per Capita (yuan) & 1307 & 2780.66 & 2665.23 & 330.00 & 24944.00 \\
Area (sq km) & 1307 & 529.04 & 402.53 & 24.00 & 1626.00 \\
Population (thousand persons) & 1307 & 271.64 & 475.40 & 1.53 & 6459.70 \\
Revenue (million yuan) & 1307 & 158.83 & 172.71 & 0.40 & 1200.00 \\
Phone ((thousand) & 1307 & 27.95 & 23.22 & 0.20 & 116.27 \\
Middle school students((thousand person) & 1307 & 18.27 & 8.94 & 4.59 & 64.87 \\
Urbanization rate (\%, non-agricultural share) & 1307
\end{tabular}

Notes: Fundamental economic information come from the Sichuan Statistic Yearbook published from 2004 to 2014. And New register firm data are from Administration of Industry and Commerce of Sichuan Province in China 2004-2013.

\section{Results}

\subsection{Baseline Results}

Table2 shows the road infrastructure investment on exports using Sichuan county-level data from 2003 to 2013 based on equation (1). Year and county fixed effects are included in the regressions, but not reported separately. The variable of interest is road length in column (1), road density of area in column (2) and road density of population in column (3). As mentioned in Section 3, road investment is the lag one period variable. On the one hand, the same period road investment may not be used efficient to transport goods, on the other hand, the future economic activities may not reverse effect on the history investment ${ }^{\mathrm{v}}$. The coefficients for the interest are significantly negative at $1 \%$ level and robustness. Suggesting counties with better road investment experienced a much larger decline in export than other counties. The stock of road investment has reduced total export by $29 \%$ (or 100(e-0.345-1)) if using 2003 as a base line. Compare this results with Figure 1 of panel B, we can find that growth of export are not contributed by the better road investment. However, this paper do not discuss the real reasons of export increasing.

The coefficient of other control variables make sense, higher income and higher urbanization rate counties export more, but the mobile phone decline the export. One reason maybe the local population use phone to detail with the private or local business, and use internet to do international business, but we cannot get this data. Other control variables effect are insignificant. All of estimation results show that our interest variable effect are robustness. 
Table 2. The impact of road investment on export (county-level)

\begin{tabular}{lccc}
\hline & $\begin{array}{c}(1) \\
\text { Log(export) }\end{array}$ & $\begin{array}{c}(2) \\
\log (\text { export })\end{array}$ & $\begin{array}{c}(3) \\
\text { Log(export) }\end{array}$ \\
\hline Lag(Road length) & $-0.345^{* *}$ & & \\
& $(0.140)$ & & \\
Lag (Road per area) & & $-0.278^{* *}$ & \\
& & $(0.141)$ & \\
Lag (Road per person) & & & $-0.330^{* *}$ \\
& & & $(0.140)$ \\
GDP per Capita & $0.697^{* *}$ & $0.689^{* *}$ & $0.692^{* *}$ \\
& $(0.305)$ & $(0.306)$ & $(0.305)$ \\
Education & -0.295 & -0.268 & -0.185 \\
& $(0.238)$ & $(0.239)$ & $(0.204)$ \\
Phone & $-0.280^{*}$ & $-0.284^{*}$ & $-0.257^{*}$ \\
& $(0.156)$ & $(0.156)$ & $(0.154)$ \\
Revenue & 0.161 & 0.153 & 0.176 \\
& $(0.164)$ & $(0.164)$ & $(0.163)$ \\
Area & -5.590 & & -5.136 \\
& $(3.471)$ & & $(3.378)$ \\
Population & 0.885 & 0.407 & \\
& $(1.009)$ & $(0.985)$ & \\
Urbanization & $0.786^{*}$ & $0.748^{*}$ & $0.841^{*}$ \\
& $(0.437)$ & $(0.437)$ & $(0.434)$ \\
Year dummy & YES & YES & YES \\
County dummy & YES & YES & YES \\
\hline N & 1307 & 1307 & 1307 \\
Adj. R2 & 0.118 & 0.115 & 0.118 \\
\hline
\end{tabular}

Note: All of the independent variables are in the logarithm form. The county cluster standard error are reported. "*","**","***" represent the $1 \%, 5 \%$ and $10 \%$ significant level respectively.

Moreover, there are also some omitted variables cannot be observed by many reasons will cause the above estimation is bias. We know that the county in Sichuan province has different type land, and suffer the big earthquake disaster at 2008. These two reasons may lead the Table 2 results are bias because of the heterogeneity problem. So we do a set of robustness check, first, we group the counties into two sub-sample, one if mountain area belong the fault line suffer the quake (disaster), the other are plain area without quake (non-disaster) ${ }^{\mathrm{vi}}$, and re-regress the equation (1), results are not difference between two groups reported in Table3a which significant are similar with Table2 Besides, that we also exclude the year 2008 to control the quake effect, the results robustness, the road investment has significant negative effect on the local export reported in Appendix Table1. 
Table 3a. Robustness check (sub-sample)

\begin{tabular}{|c|c|c|}
\hline & Non-disaster counties & Non-paired disaster counties \\
\hline \multirow[t]{2}{*}{ Lag(Road length) } & $-0.615 * * *$ & $-0.262 * *$ \\
\hline & $(0.102)$ & $(0.102)$ \\
\hline \multirow[t]{2}{*}{ GDP per Capita } & $1.378 * * *$ & $1.369 * * *$ \\
\hline & $(0.469)$ & $(0.404)$ \\
\hline \multirow[t]{2}{*}{ Education } & -0.357 & $-0.624 * *$ \\
\hline & $(0.265)$ & $(0.251)$ \\
\hline \multirow[t]{2}{*}{ Phone } & $-0.349 *$ & -0.152 \\
\hline & $(0.192)$ & $(0.173)$ \\
\hline \multirow[t]{2}{*}{ Revenue } & -0.101 & -0.170 \\
\hline & $(0.192)$ & $(0.181)$ \\
\hline \multirow[t]{2}{*}{ Area } & 6.812 & $6.624 *$ \\
\hline & $(5.687)$ & $(3.716)$ \\
\hline \multirow[t]{2}{*}{ Population } & $3.508 * * *$ & $3.361 * * *$ \\
\hline & $(1.107)$ & $(1.117)$ \\
\hline \multirow[t]{2}{*}{ Urbanization } & $1.815^{* * *}$ & $1.622 * * *$ \\
\hline & $(0.592)$ & $(0.491)$ \\
\hline Year dummy & YES & YES \\
\hline County dummy & YES & YES \\
\hline $\mathrm{N}$ & 1307 & 1307 \\
\hline Adj. R2 & 0.659 & 0.701 \\
\hline
\end{tabular}

Note: Column (1) except the disaster counties, and column (2) except the disaster counties with receive the pairwise aid counties (eg., definition from Bulte et al., 2013). Disaster are local at the mountain area, which also show that the results are robustness even though there is the land type heterogeneous bias. All of the independent variables are in the logarithm form. The county cluster standard error are reported. "*","**","***" represent the $1 \%, 5 \%$ and $10 \%$ significant level perceptively.

As mentioned in above sections, we argue that the road investment has short term effect on the local export through different sectors, because relative price of non-tradable and tradable goods will rise in short term. So we also estimate road investment effect on the growth rate of export (defined as export in period $t$ over period t-1) to capture the short term effect. And the results are reported in Table $3 b$, except the road density of area ${ }^{\text {vii }}$, the interest variable has significant negative effect on export consistence effect with Table 2. However, here we use the random effect instead of fixed effect, because the first order difference may not relate with the error, Hausman test proof this assumption (Prob>chi2 $=0.963$ cannot reject the hull hypothesis that error term is uncorrelated with dependent variables). 
Table 3b. Robustness check (growth rate)

\begin{tabular}{lccc}
\hline & $(1)$ & $(2)$ & $(3)$ \\
& Change of export & Change of export & Change of export \\
\hline Lag(Road length) & $-0.410^{* *}$ & & \\
Lag (Road per area) & $(0.196)$ & & \\
& & -0.268 & \\
Lag (Road per person) & & $(0.163)$ & $-0.391 * *$ \\
& & & $(0.182)$ \\
GDP per Capita & 0.328 & 0.221 & 0.302 \\
& $(0.325)$ & $(0.317)$ & $(0.312)$ \\
Education & 0.206 & 0.215 & 0.252 \\
Phone & $(0.250)$ & $(0.251)$ & $(0.191)$ \\
& 0.055 & 0.070 & 0.069 \\
Revenue & $(0.208)$ & $(0.208)$ & $0.202)$ \\
Area & 0.055 & 0.066 & $(0.159)$ \\
& $(0.164)$ & $(0.164)$ & -0.213 \\
Population & 0.194 & & $(0.168)$ \\
& $(0.151)$ & & \\
Urbanization & 0.089 & -0.328 & \\
Year dummy & $(0.315)$ & $(0.307)$ & $-0.449 *$ \\
N & $-0.430 *$ & $-0.459 *$ & $(0.246)$ \\
Adj. R2 & $(0.256)$ & $(0.256)$ & YES \\
\hline
\end{tabular}

Note: Change of export defined as growth rate over last year, and is 1 if last year has no export. All of the independent variables are in the logarithm form. The county cluster standard error are reported. "*","***","***" represent the 1\%,5\% and $10 \%$ significant level respectively. Here we use the random effect because the first order difference may not relate with the error term, Hausman test proof this assumption (Prob>chi2 $=0.963$ cannot reject the hull hypothesis that error term is uncorrelated with dependent variables).

\subsection{The Transmission Channel}

So what are the major transmission channels for the declining export in better road investment counties? Of course, there are many potential culprits. The simplest explanation would be that the underdevelopment industrialization counties with lower population density, but they may has longer road length. However, we have shown that given the urbanization rate and fixed the county effect, the road length per population or per area also restrict the export (see Table2). Besides that, we also the split counties into two groups, one is higher industrial development, defined as with urbanization rate higher than the median ratio over years, and less than that thresholds are defined as lower industrial development counties ${ }^{\text {viii }}$. Then re-regress Table 2 result within two sub-samples, results are reported in Table3c, Panel A show the higher development of industrial sector, and Panel B is the lower development of industrial sector. However, these results are contrary to the above logic, these show that counties has better road investment may reduce the export even in a better development of industrial sectors instead of under-development areas. This suggests that the higher road density counties has less export than lower ones, especially in the higher urbanization areas. 
Table 3c. Robustness check (sub-sample according urbanization)

\begin{tabular}{|c|c|c|c|}
\hline & $\begin{array}{c}(1) \\
\log (\text { export })\end{array}$ & $\begin{array}{c}(2) \\
\log (\text { export })\end{array}$ & $\begin{array}{c}(3) \\
\log (\text { export })\end{array}$ \\
\hline & \multicolumn{3}{|c|}{ Panel A: urbanization rate $(>=15.3 \%)$} \\
\hline $\operatorname{Lag}($ Road length) & $\begin{array}{c}-0.467 * * \\
(0.199)\end{array}$ & & \\
\hline Lag (Road per area) & & $\begin{array}{c}-0.420 * * \\
(0.199)\end{array}$ & \\
\hline Lag (Road per person) & & & $\begin{array}{c}-0.449 * * \\
(0.199)\end{array}$ \\
\hline Year dummy & YES & YES & YES \\
\hline County dummy & YES & YES & YES \\
\hline $\mathrm{N}$ & 682 & 682 & 682 \\
\hline Adj. R2 & 0.068 & 0.063 & 0.057 \\
\hline Lag(Road length) & $\begin{array}{c}\text { Panel B: Low } \\
0.053 \\
(0.198)\end{array}$ & urbanization & te $(<15.3 \%)$ \\
\hline Lag (Road per area) & & $\begin{array}{c}0.077 \\
(0.197)\end{array}$ & \\
\hline Lag (Road per person) & & & $\begin{array}{c}0.059 \\
(0.199)\end{array}$ \\
\hline Year dummy & YES & YES & YES \\
\hline County dummy & YES & YES & YES \\
\hline $\mathrm{N}$ & 625 & 625 & 625 \\
\hline Adj. R2 & 0.124 & 0.117 & 0.111 \\
\hline
\end{tabular}

Note: Median urbanization rate over 11 years is $15.3 \%$, lowest is $4.6 \%$, and highest is $64.9 \%$. Panel A restrict the sample within higher urbanization rate group ( $>=15.3 \%$ ), and Panel B restrict the sample within lower urbanization rate group $(<15.3 \%)$. All of the independent variables are in the logarithm form same with Table2 do not report here. The county cluster standard error are reported. "*","**","***" represent the $1 \%, 5 \%$ and $10 \%$ significant level respectively.

Hence, rising relative price as discussed in the previous sections is one potential transmission channel. We can probe the nature of the transmission mechanism a little further, using additional data. Thanks to the massive road investment inflow, there was first boom the non-tradable sectors, such as housing, retail, restaurant, transportation, hotel, etc., which stimulate the demand of non-skill labors and attract the capital investment on this sectors. Using data obtained in New Registered Firm data from Administration of Industry and Commerce of Sichuan Province in China from 2003 to 2013. Table 4 reports the road investment effect on the capital flow by two different sectors. Column (1) estimate the effect on the total new investment measured by total new register firm numbers, column (2) test the effect on capital flow into manufacturing sectors, and column (3) test the capital flow into service sectors. Besides that, we also do the robustness check using three measurements of road investment, road length in Panel A, road density of area in Panel B, and road density of population if Panel C. All of these results show that the road investment hinders the private capital investment flow to tradable sectors, but stimulate the investment on service sectors. These results are robustness within different periods, such as drop the quake year 2008 (see Appendix Table2). Then the non-tradable sectors demand of labor is increased, the price and wage are higher than average, so non-skill labor will move from the manufacturing firms to the service sectors ${ }^{\mathrm{ix}}$. In short run, the manufacturing need reduce the producing line or rise wage, but the price is determined by the international market, it cannot shape quickly, so all of these firms have to reduce the production, export are restricted. However, we cannot provide the price change or wage gap evidence to further test this channels, because the local wage is the average wage only observed at the equilibrium in our data set. This is our big limitation need to investigate in the future. 
Table 4. Road investment effect on the new register firm by sectors (Capital channel )

\begin{tabular}{|c|c|c|c|}
\hline & $(1)$ & $(2)$ & (3) \\
\hline & Log (Total new firms) & $\%$ of manu. firm & $\%$ of serv. firm \\
\hline & \multicolumn{3}{|c|}{ Panel A: Road length } \\
\hline \multirow[t]{2}{*}{ Lag(Road length) } & $0.075 * *$ & $-1.023^{*}$ & $2.309 *$ \\
\hline & $(0.030)$ & $(0.571)$ & $(1.275)$ \\
\hline Control variables & YES & YES & YES \\
\hline County fixed effect & YES & YES & YES \\
\hline Year dummy & YES & YES & YES \\
\hline $\mathrm{N}$ & 1307 & 1307 & 1307 \\
\hline adj. $R^{2}$ & 0.245 & -0.005 & 0.032 \\
\hline \multirow{3}{*}{$\operatorname{Lag}(\operatorname{Road}$ density of area $)$} & \multicolumn{3}{|c|}{ Panel B: robustness check } \\
\hline & $0.066 * *$ & $-1.080 *$ & $2.187 *$ \\
\hline & $(0.030)$ & $(0.571)$ & $(1.275)$ \\
\hline Control variables & YES & YES & YES \\
\hline County fixed effect & YES & YES & YES \\
\hline Year dummy & YES & YES & YES \\
\hline $\mathrm{N}$ & 1307 & 1307 & 1307 \\
\hline adj. R2 & 0.245 & -0.007 & 0.030 \\
\hline \multirow{3}{*}{ Lag(Road density of population ) } & \multicolumn{3}{|c|}{ Panel C: robustness check } \\
\hline & $0.075^{* *}$ & $-1.042 *$ & $2.347 *$ \\
\hline & $(0.030)$ & $(0.571)$ & $(1.278)$ \\
\hline Control variables & YES & YES & YES \\
\hline County fixed effect & YES & YES & YES \\
\hline Year dummy & YES & YES & YES \\
\hline $\mathrm{N}$ & 1307 & 1307 & 1307 \\
\hline adj. R2 & 0.241 & -0.006 & 0.025 \\
\hline
\end{tabular}

Note: The control variables of Panel A, B and C are same as column (1), (2) and (3) of Table 2 respectively. The county cluster standard error are reported. "*","**","***" represent the $1 \%, 5 \%$ and $10 \%$ significant level respectively.

Whether the employment by sectors are shaped by the road investment? We also take a future investigate, using the county-level employment by sectors data, re-regress the road effect on the share of employment in two sectors. Table5 shows that better road density reduce the share of industrial employment significantly, but has little effect on the service sectors. But these results may not robustness because data limitation, which we only can observe the employment work at local area, and cannot capture effect on migration to other province. 
Table 5. Road investment effect on the employment by sectors (Labor channel )

\begin{tabular}{|c|c|c|}
\hline & $(1)$ & $(2)$ \\
\hline & $\%$ of manu. & $\%$ of serv. \\
\hline & \multicolumn{2}{|c|}{$\underline{\text { Panel A: Road length }}$} \\
\hline \multirow[t]{2}{*}{ Lag(Road length) } & $-0.959 * * *$ & -0.281 \\
\hline & $(0.305)$ & $(0.368)$ \\
\hline Control variables & YES & YES \\
\hline County fixed effect & YES & YES \\
\hline Year dummy & YES & YES \\
\hline $\mathrm{N}$ & 1307 & 1307 \\
\hline \multirow[t]{2}{*}{ adj. $\mathrm{R}^{2}$} & 0.284 & 0.078 \\
\hline & \multicolumn{2}{|c|}{ Panel B: Robustness check } \\
\hline \multirow[t]{2}{*}{$\operatorname{Lag}(\operatorname{Road}$ density of area $)$} & $-0.965 * * *$ & -0.315 \\
\hline & $(0.305)$ & $(0.368)$ \\
\hline Control variables & YES & YES \\
\hline County fixed effect & YES & YES \\
\hline Year dummy & YES & YES \\
\hline $\mathrm{N}$ & 1307 & 1307 \\
\hline \multirow[t]{2}{*}{ adj. R2 } & 0.285 & 0.078 \\
\hline & \multicolumn{2}{|c|}{ Panel C: Robustness check } \\
\hline \multirow[t]{2}{*}{ Lag(Road density of population $)$} & $-0.970 * * *$ & -0.300 \\
\hline & $(0.306)$ & $(0.371)$ \\
\hline Control variables & YES & YES \\
\hline County fixed effect & YES & YES \\
\hline Year dummy & YES & YES \\
\hline $\mathrm{N}$ & 1307 & 1307 \\
\hline adj. R2 & 0.280 & 0.064 \\
\hline
\end{tabular}

Note: The control variables of Panel A, B and C are same as column (1), (2) and (3) of Table 2 respectively. The county cluster standard error are reported. "*","**","***" represent the 1\%,5\% and 10\% significant level respectively.

Because the data limitation, we cannot control the size of new register firms. And some argue that the size of manufacturing firm, or entry cost may higher than service, the new firm start-up is lower than service sector. Using number of new registered firms may have measurement error. So, we split the sample into manufacturing and service sectors and use panel data to estimate the road effect separately. It means when we control the sectors' owner characteristics and its trends, the results are robustness. Such as, in table 4 column (2), the result shows that the detrend growth rate of new private capital of manufacturing is restricted by road investment given the total new investment. And road increases the growth rate of investment on service sector. We do not compare the number of new registered firms by these two sectors directly.

\section{Conclusion}

The relation between road infrastructure investment cross-country in growth models have been unable to document robust evidence of positive effect. One prominent explanation for the absence of such effects is "Market Access" hypothesis, which argues that better road connected will reduce the transaction cost and benefit aggregate export. "Local road density" hypothesis argue that market access undermine the profitability of the different regions may has different effects. If only focus on the local area, the better road density promote the productive of manufacturing sectors by caused reduce the inventory cost. However, all of these studies ignore the different effect on service sector, which may reverse to impact on the tradable firms, and the relative price will be shaped in short term, labor and capital may flow between tradable and non-tradable sectors. If the non-tradable sectors are boomed first, then the labor and capital will flow into higher productivity sectors, hence restrict the relative lower sectors, such as manufacturing, and export are hinder.

In this paper we seek to contribute to the literature on the effectiveness of road investment by focusing on its different effect on sectors in a specific geographical area (Sichuan province, in China). Indeed, this is one of the first papers to 
probe the consequences of road investment effect on between tradable and non-tradable sectors before the local wage converge to the equilibrium level. The recent development in Sichuan of China provides us with a good opportunity to gain a better understanding of the economic consequences of road investment. Hopefully the research findings will also be relevant for other less fortunate regions.

Our main question is whether the road infrastructure investment is a factor explaining export. To explore this issue, we employ a simple panel fixed effect models, and using a set of data to estimate it. All the methods unanimously support to hypothesis 1 , the road has significantly negative effect on local export, i.e. higher road investment counties has less export in the short run. Specifically, we find that (i) road investment reduce the new firm entry growth rate of manufacturing sector; (ii) better road investment stimulate the more private capital flow into service sectors; (iii) employment of industrial has been restricted caused by road investment. Hence, the road investment tends to cause contraction of the manufacturing sector. More tentatively, we also document that (temporary) increases in the prices of non-tradable sectors are a potential transmission mechanism linking road to export decline. Of course it remains an urgent priority for future work to explore long-term effects also seems useful.

The purpose of this paper was not to evaluate the policy impact of road investment policy, and we do not tend to judge whether the county need to investment on road. This conclude implicit that policy maker need to consider both the short and long-term effects of the road investment. Our aim is much more modest, and is restricted to identifying whether road investment has negative effect on local export, if it consider the relative effect on the linked two sectors (Tradable and non-tradable). But caused by data limitation, we cannot provide the price change or wage gap by sectors evidence.

\section{Acknowledgments}

Lihe $\mathrm{Xu}$ is grateful for financial support from National Nature Science Foundation of China (No. 71603216)

\section{References}

Banerjee, A., Duflo, E., \& Qian, N. (2012). On the Road: Access to Transportation Infrastructure and Economic Growth in China, NBER working paper No. 17897.

Bulte E, Xu, L., \& Zhang, X. (2018). Post-disaster Aid and Development of the Manufacturing sector: Lessons from a Natural Experiment in China. European Economic Review, 101,441-458 https://doi.org/10.1016/j.euroecorev.2017.10.019

Donaldson, D. (2010). Railroads of the Raj: Estimating the Impact of Transportation Infrastructure. American Economic Review, 32(2), 164-87. https://doi.org/10.3386/w16487

Donaldson, D., \& Hornbeck, R. (2013). Railroads and American Economic Growth: A "Market Access" Approach, NBER Working Paper No. 19213. https://doi.org/10.1093/restud/rdt039

Duranton, G., Morrow, P. M., \& Turner, M. A. (2013), Roads and Trade: Evidence from the US. Review of Economic Studies, 81(2), 681-724. https://doi.org/10.1093/restud/rds010

Duranton, G., \& Turner, M. A. (2008). Urban Growth and Transportation. Review of Economic Studies, 79(4), 1407-1440.

Faber, B. (2014). Trade Integration, Market Size, and Industrialization: Evidence from China's National Trunk Highway System. Review of Economic Studies, 81(3), 1046-1070. https://doi.org/10.1093/restud/rdu010

Farhadi, M. (2015). Transport Infrastructure and Long-run Economic Growth in OECD Countries. Transportation Research Part A, 74, 73-90. https://doi.org/10.1016/j.tra.2015.02.006

Fogel, R. W. (1964). Railroads and American Economic Growth: Essay in Economic history, Johns Hopkins University Press, Baltimore.

Garcia-López, M. Á., Holl, A., \& Viladecans-Marsal, E. (2015), Suburbanization and Highways in Spain when the Romans and the Bourbons still Shape its Cities. Journal of Urban Economics, 85, 52-67. https://doi.org/10.1016/j.jue.2014.11.002

Holl, A. (2016). Highways and Productivity in Manufacturing Firms. Journal of Urban Economics, 93,131-151. https://doi.org/10.1016/j.jue.2016.04.002

Hong, J., Chu, Z., \& Wang, Q. (2011). Transport Infrastructure and Regional Economic growth: Evidence from China. Transportation, 38(5), 737-752. https://doi.org/10.1007/s11116-011-9349-6

Jacoby, H. G. (2000) Access to Markets and the Benefits of Rural Roads. Economic Journal, 110(465), $713-37$. https://doi.org/10.1111/1468-0297.00562

Li, H., \& Li, Z. (2013). Road Investments and Inventory Reduction: Firm level Evidence from China. Journal of Urban 
Economics, 76(2), 43-52. https://doi.org/10.1016/j.jue.2013.02.002

Meng, X. (2005). Introduction: Poverty and Labor Markets in China. Journal of Comparative Economics, 33(4), 641643. https://doi.org/10.1016/j.jce.2005.08.003

Michaels, G. (2008). The Effect of Trade on the Demand for Skill: Evidence from the Interstate Highway System. The Review of Economics and Statistics, 90(4), 683-701.

Rong, Z., \& Gong, Q. (2013). Does Housing Bubble restrict the R\&D Investment? working paper.

Shirley, C., \& Winston, C. (2004). Firm Inventory Behavior and the Returns from Highway Infrastructure Investments Journal of Urban Economics, 55(2), 398-415.

Song, M., Wang, S., \& Fisher, R. (2014). Transportation, Iceberg Costs and the Adjustment of Industrial Structure in China. Transportation Research Part D Transport \& Environment, 32, 278-286.

https://doi.org/10.1016/j.trd.2014.08.005

\section{Copyrights}

Copyright for this article is retained by the author(s), with first publication rights granted to the journal.

This is an open-access article distributed under the terms and conditions of the Creative Commons Attribution license (http://creativecommons.org/licenses/by/4.0/).

\footnotetext{
${ }^{\mathrm{i}}$ Rong and Gong (2013) argue that boom of China's housing sectors crowding out the manufacturing firm 's innovation investment.

ii See Yao (2009) and Fan et al. (2011) introduction about the Western of China's development, such as "Go Western Policy".

iii Banerjee et al. (2012), Donaldson and Hornbeck (2013) summarize the detail information of railroad effect on the export.

${ }^{\text {iv }}$ For example, see Meng (2005) introduce the migration patterns in China.

${ }^{v}$ We use lag from to avoid the reverse causality endogenous bias, which is not the best method to solve this. But our study just focus on test the stock of road investment effect on economics, we do not argue that whether a county need road investment or not.

vi The definition is consistence with Bulte et al. (2018).

vii Road density of area has little variation after the first order difference, so there has no results.

viii Median urbanization rate over 11 years is $15.3 \%$, lowest is $4.6 \%$, the higher is $64.9 \%$.

${ }^{\text {ix }}$ The assumption is manufacturing firm are labor intensive in all counties.
} 